\title{
Prevalence and Genetic Variability in Capsid L1 Gene of Rare Human Papillomaviruses (HPV) Found in Cervical Lesions of Women from North-East Brazil
}

\author{
Ana Pavla Almeida Diniz Gurgel, ${ }^{1}$ Bárbara Simas Chagas, ${ }^{1}$ \\ Carolina Maria Medeiros do Amaral, ${ }^{1}$ Eugênia Maria Bezerra Albuquerque, \\ Ivi Gonçalves Soares Santos Serra, ${ }^{3}$ Jacinto da Costa Silva Neto, ${ }^{4}$ \\ Maria Tereza Cartaxo Muniz, ${ }^{5}$ and Antonio Carlos de Freitas ${ }^{1,6}$ \\ ${ }^{1}$ Department of Genetics, Federal University of Pernambuco, Brazil \\ ${ }^{2}$ Gynaecological Unit, University Hospital Oswaldo Cruz, Brazil \\ ${ }^{3}$ Gynaecological Unit, Integrated Medicine Center, Brazil \\ ${ }^{4}$ Department of Histology and Embryology, Federal University of Pernambuco, Brazil \\ ${ }^{5}$ Molecular Biology Laboratory, Pediatric Oncohematology Center, University of Pernambuco, Brazil \\ ${ }^{6}$ Cidade Universitária, 50670-901, Recife, PE, Brazil \\ Correspondence should be addressed to Antonio Carlos de Freitas; acf_ufpe@yahoo.com.br
}

Received 20 February 2013; Revised 30 April 2013; Accepted 9 May 2013

Academic Editor: Franco Roperto

Copyright (C) 2013 Ana Pavla Almeida Diniz Gurgel et al. This is an open access article distributed under the Creative Commons Attribution License, which permits unrestricted use, distribution, and reproduction in any medium, provided the original work is properly cited.

\begin{abstract}
The aim of this study was to examine the prevalence and genetic variability of the capsid Ll gene of rare HPV genotypes that were found in the cervical lesions of women from North-East Brazil. A total number of 263 patients were included in this study. HPV detection was performed using PCR followed by direct sequencing of MY09/11, as well as type-specific PCR to detect the Alpha9 species. Epitope prediction was performed to determine whether or not the genetic variants are inserted in B-cell and T-cell epitopes. The prevalence of rare HPV types in cervical lesions was found to be $9.47 \%$. The rare HPV genotypes that were detected were HPV-53, 54, 56, 61, 62, 66, 70, and 81. The genetic variability in the L1 gene of rare HPV types involved thirty nucleotide changes, eight of which were detected for the first time in this study. Moreover, some of these variants are embedded in B-cell or T-cell epitope regions. The results of this research suggest that rare HPV types might be involved in cervical lesions and some of these variants can be found in B-cell and T-cell epitopes. Data on the prevalence and variability of rare HPV types will assist in clarifying the role of these viruses in carcinogenesis.
\end{abstract}

\section{Introduction}

Cervical cancer is ranked as the third major cause of female cancer worldwide, with an estimate of more than 529,000 new cases diagnosed and 275,000 deaths in 2008 [1]. In developing countries, cervical cancer comprises $85 \%$ of the total number of cases [1] and in Brazil, cervical cancer is the third most common cancer among women [2].

Persistent infections caused by Human Papillomavirus (HPV) can result in cervical lesions and cervical cancer [3]. $\mathrm{HPV}$ is a nonenveloped virus with a circular double-stranded DNA [4]. This virus group belongs to the Papillomaviridae family, which comprises 29 genera and 189 Papillomaviruses (PV) [5]. To date, more than $120 \mathrm{HPV}$ types have been identified and these can be divided into five genera: Alphapapillomavirus (Alpha), Betapapillomavirus (Beta), Gammapapillomavirus (Gamma), Mupapillomavirus (Mu), and Nupapillomavirus (Nu) [5, 6]. Among these, $40 \mathrm{HPV}$ types infect the genital tract, 15 of which are considered to be High-Risk (HR) HPV (16, 18, 31, 33, 35, 39, 45, 51, 52, 56, 58, 59, 68,73 , and 82 ); six species are considered Low-Risk (LR) HPV $(6,11,42,44,51,81$, and 83$)$ and three species are considered Intermediate Risk (IR) HPV $(26,53,66)$ [7]. The International 
Table 1: Primer sequence used to detect HPV-16, 31, 33, and 58 genotypes.

\begin{tabular}{|c|c|c|}
\hline HPV genotype (LCR) & Sequence primer & Amplicon size (base pairs) \\
\hline HPV-16 & $\begin{array}{c}\text { F: } 5^{\prime} \text {-TTCTGCAGACCTAGATCAGTTTC- } 3^{\prime} \\
\text { F: } 5^{\prime} \text {-GTGCATAACTGTGGTAACTTTCTGG-3 }\end{array}$ & $1057 \mathrm{bp}$ \\
\hline HPV-31 & $\begin{array}{l}\text { F: 5' -TTAGATCAGTTTCCACTGGGTCG-3' } \\
\text { F: } 5^{\prime} \text {-TTAGTTCATGCAATTTCCGAGGTC-3' }\end{array}$ & $1152 \mathrm{bp}$ \\
\hline HPV-33 & $\begin{array}{c}\text { F: } 5^{\prime} \text {-TACCTCCAAAGGAAAAGGAAGACCC-3' } \\
\text { F: } 5^{\prime} \text {-TTGGCACAAATCATGCAATGTTCG-3' }\end{array}$ & 1184 bp \\
\hline HPV-58 & $\begin{array}{c}5^{\prime} \text { CATGTTCTATGTCCTTGTCAG 3' } \\
5^{\prime} \text { TGA CCC AAA ACG GTT AGT CC } 3^{\prime}\end{array}$ & $1000 \mathrm{bp}$ \\
\hline
\end{tabular}

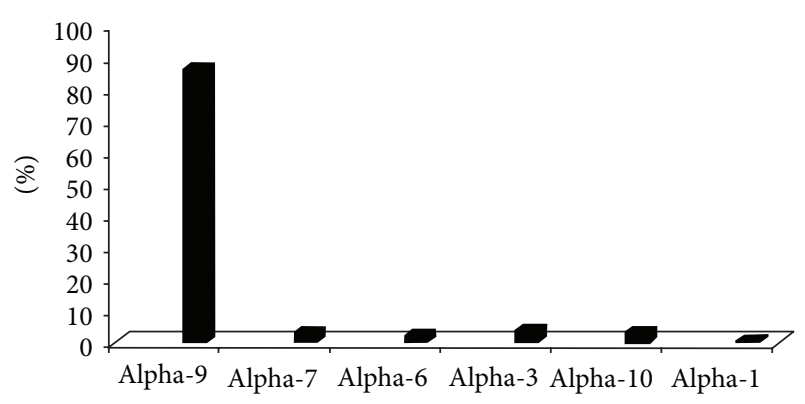

Figure 1: Percentage of Alphapapillomavirus species in cervical lesions of women from Pernambuco and Sergipe States, Northeast Brazil. The figure shows the high frequency of A9 species (86.46\%), followed by A3 (4.2\%), A10 (3.4\%), A7 (3.4\%), A6 (2.5\%), and Alpha$1(0.8 \%)$ HPV genotypes.

Agency for Research on Cancer (IARC) recognizes the HPV$16,18,31,33,35,39,45,51,56,58,59$, and 68 as carcinogenic or probably carcinogenic groups [8]. Moreover, HPV that have a phylogenetic relationship with other carcinogenic HPV are regarded as possibly carcinogenic groups, called Alpha-5, Alpha-6, Alpha-7, Alpha-9, and Alpha-11 species [7].

Recently, epidemiological data on the worldwide incidence of HPV have shown that Alpha-9 and Alpha-7 species cause $91 \%$ of invasive cervical cancer [9]. HPV-16, 18, and 45 are responsible for $75 \%$ of squamous cell carcinoma and $74 \%$ of the adenocarcinoma cases [9]. Despite the high prevalence of Alpha-9 and Alpha-7 species, other Alpha species are involved in cervical cancer, though only to a very limited degree. For instance, in 2010 it was reported that $2.25 \%$ of total invasive cervical cancer were caused by rare HPV types [9].

There have been several studies that describe the prevalence and genetic variability of the HPV-16, HPV-18, HPV31, and HPV-58 genotypes [9-21]. However, few studies have shown the extent of the prevalence and variability of rare HPV types in infected women [9, 16, 22, 23]. Rare HPV types might be involved in cervical cancer due to the genetic variability, especially when these changes are found in linear B-cell or T-cell epitopes, which theoretically allow the escape recognition by the innate immune system. Furthermore, it is still unknown what role they play in the single infections or coinfections that result in cervical lesions and cervical cancer.

Thus, the aim of this study was to investigate the prevalence of rare HPV types, as well as the genetic variability of the capsid L1 gene of these viruses, in cervical lesions of women from North-East Brazil.

\section{Material and Methods}

2.1. Population. Cervical cells were collected from November 2010 to August 2011. The samples were obtained from women during their medical consultations at the Gynaecological Unit of the Integrated Medicine Center, in Sergipe State and the Oswaldo Cruz University Hospital, in Pernambuco State, North-East Brazil. A total number of 263 women agreed to participate in the study and signed the consent form. The study included patients with Cervical intraepithelial Neoplasia (CIN) (Grade - I, II, III) and cervical invasive cancer. All the patients were sexually active and their average age was 38.02 (with ages ranging from 16 to 77). This study was approved by the Ethics Committee of the University of Pernambuco (HUOC/PROCAPE 64/2010) and the Ethics Committee of the Federal University of Sergipe (CEP/CCS/UFPE N 491/11).

2.2. DNA Extraction and HPV Genotyping. The collected cells were placed in polyethylene tubes containing phosphatebuffered saline and then stored at $-20^{\circ} \mathrm{C}$ until analysis. DNA was extracted by using the DNeasy Blood and Tissue Kit 135 (Qiagen) in accordance with the manufacturer's instructions.

HPV DNA detection was performed by using polymerase chain reaction (PCR) with degenerate primers MY09/11 [24], which amplify fragments containing $450 \mathrm{bp}$ from the L1 gene of a wide spectrum of HPV types. In addition, a possible coinfection caused by HPV-16, 31, 33, and HPV-58 was detected through type-specific PCR using primers that target the long control region (LCR), which only allow amplification of the $1000 \mathrm{bp}$ of LCR of each of the above-mentioned HPV genotypes (the primer sequences are described in Table 1) (Figure 1). The reactions were performed with a final volume of $25 \mu \mathrm{L}$ containing $100 \mathrm{ng}$ of DNA, $1.5 \mathrm{mM}$ of $\mathrm{MgCl}_{2}, 50 \mu \mathrm{M}$ of each dNTP, 20 pmol of each primer, and 1 unit of Taq DNA Polymerase and $1 \mathrm{x}$ buffer. The PCR cycling conditions were as follows: initial denaturation at $95^{\circ} \mathrm{C}$ for 5 minutes, 35 cycles of denaturation at $95^{\circ} \mathrm{C}$ for 30 seconds, annealing at $55^{\circ} \mathrm{C}$ for 1 minute, elongation at $72^{\circ} \mathrm{C}$ for 2 minutes, and a final extension at $72^{\circ} \mathrm{C}$ for 10 minutes. The PCR products were run on the agarose gel (1\%).

The positive samples were purified with the Invisorb Fragment Cleanup (Invitek) kit and sequenced (in duplicate) by using ABI PRISM BigDye Terminator Cycle Sequencing v 3.1 Ready Reaction (Applied Biosystems) to obtain both the forward and reverse sequences. 
TABLE 2: Rare HPV type found in cervical intraepithelial neoplasia grades I, II, III and invasive cervical cancer.

\begin{tabular}{lc}
\hline Rare HPV type & Histopathological grade \\
\hline HPV-53 & CIN III \\
HPV-54 & CIN I \\
HPV-56 & CIN I \\
HPV-61 & CIN II \\
HPV-62 & CIN III \\
HPV-66 & CIN I \\
HPV-70 & CIN I/Adenocarcinoma \\
HPV-81 & CIN I \\
\hline
\end{tabular}

The sequences obtained were assembled into contigs using the Staden package [25]. They were then evaluated to determine the nucleotide divergence relative to the L1 nucleotide sequences of HPV-53 (NC_001593.1), HPV54 (NC_001676.1), HPV-56 (X74483.1), HPV-61 (U31793.1), HPV-62 (AY395706), HPV-70 (U21941.1), and HPV-81 (AJ620209). Sequence comparisons were performed using the Basic Local Alignment Search Tool (BLAST) and multiple alignments were carried out by CLUSTALW (Mega 5, Beta version) program [26].

New variants were submitted to GeneBank with the following accession numbers: HPV-53-JX912952; HPV-54JX912948; HPV-56-JX912947; HPV-62-JX912951; HPV-70JX912950 and HPV-81-JX912949.

2.3. B-Cell and T-Cell Epitope Prediction. The putative impact of variability in L1 gene of rare HPV types was estimated in silico by predicting the B-cell and T-cell epitopes. In this study, it was assumed that changes in amino acid sequences of L1 proteins within B-cell and T-cell epitope regions could affect the binding affinities of the neutralizing antibodies and did not initiate an epitope-specific immune response, respectively. Thus, the B-cell epitope of prototype sequences was predicted by using the BcePred server, which is available from URL: http://www.imtech.res.in/raghava/bcepred/. The prediction was carried out with the aid of physico-chemical parameters, such as hydrophilicity, flexibility/mobility, accessibility, polarity, exposed surface, turns, and antigenic propensity [27].

The T-cell epitope predictions were performed by using ProPred and ProPred I servers. ProPred I server (available from URL: http://www.imtech.res.in/raghava/propred1/) was used to predict MHC Class-I binding regions [28], while the ProPred server (available from URL: http://www.imtech .res.in/raghava/propred/) was used to predict MHC Class-II binding peptide [29].

\section{Results}

3.1. Characteristics of the Population. A total of 263 cervical smear tests were carried out to detect HPV DNA. Of these, 95 cervical smears were submitted to variability studies because they were positive to HPV and also for histopathological findings (CIN I, II, III and invasive cervical cancer). These samples were genotyped and the results showed the presence of HPV-6, 11, 16, 18, 31, 33, 45, and 58 genotypes. With regard to rare HPV types, the following genotypes were detected: HPV-53, 54, 56, 61, 62, 66, 70, and 81 (Table 2). Among these, $9.47 \%$ were infected with rare HPV types, while $7.37 \%$ of the samples were infected with rare HPV types but without coinfection with other Alpha-9 species.

Twenty-seven cervical samples were coinfected, out of which eleven were infected with the HPV-16/31 genotype, two infected with HPV-16/18, six samples with HPV-31/58, two samples with HPV-16/33, and the remaining samples infected with the following genotypes: HPV-16/58, HPV-16/6, HPV16/33, HPV-31/33, HPV-16/54, and HPV-16/58/33.

With regard to the Alpha species, it was found that $86.46 \%$ of the positive HPV DNA samples were infected with Alpha-9, followed by Alpha-3 (4.2\%), Alpha-7 (3.4\%), Alpha-10 (3.4\%), Alpha-6 (2.5\%), and Alpha-1 (0.8\%) species (Figure 1).

3.2. Analysis of Variability. HPV-53 was obtained from patients with HSIL but without coinfection with HPV-16, $18,31,33$, and 58 types. The analysis of the variability of the L1 gene revealed single nucleotide exchanges in six positions, when compared with the reference sequence. Among these, the mutation point C6942T led to amino acid changes involving $\mathrm{P} 430 \mathrm{~S}$ in the protein sequence of the L1 (Table 3(a)). Furthermore, the epitope predictions of the HPV-53 L1 protein sequence enabled us to observe that the $\mathrm{P} 430 \mathrm{~S}$ variation is embedded in the T-cell and B-cell epitope binding regions (Table 3(a)) (Tables 4 and 5).

The patient infected with HPV-54 was coinfected with the HPV-16 type. The L1 genetic variability showed single nucleotide exchanges in five positions when compared with the reference sequence. The A6622T and T6625C mutations have never been described until now. These two mutation points lead to Q313H and S333T amino acid changes in the L1 protein sequence, respectively (Table 3(b)). An analysis of peptide prediction showed that $\mathrm{Q} 313 \mathrm{H}$ and $\mathrm{T} 333 \mathrm{~S}$ variations were found within the T-cell and B-cell epitope binding regions (Table 3(b)) (Tables 4 and 5).

HPV-81 was detected in one sample with CIN I but without coinfection with HPV-16, 18, 31, 33, and 58 genotypes. An analysis of the genetic variability of L1 showed a new synonymous mutation at the A7148G position (Table 6(a)). The sample infected with HPV-56 was observed without coinfection with other Alpha-9 species (Table 6(b)). Two synonymous mutations were observed in HPV-56 A6666G and A6987G. Moreover, HPV-61 and HPV-66 showed no nucleotide sequence divergence in the L1 gene when compared with the reference sequence.

The analysis of the L1 of HPV-70 was detected in two cervical samples with histopathological findings of adenocarcinoma and CIN I, but without coinfection with HPV$16,18,31,33$, and 58 genotypes. The sequence variation of these viruses showed five mutation points, one of which was a nonsynonymous variant. A6886G variation leads to a change in the amino acid (T433A). Furthermore, the T433A mutation is embedded in the $\mathrm{T}$-cell and $\mathrm{B}$-cell epitope binding regions (Table 6(c)) (Tables 4 and 5). 
TABLE 3: Nucleotide sequence variation in the L1 gene of HPV-53 and HPV-54. The vertical numbers indicate the position of the nucleotide variations. HG: Histopathological grade. $\left({ }^{*}\right)$ Substitutions not previously reported.

(a)

\begin{tabular}{|c|c|c|c|c|c|c|c|}
\hline & 6 & $\begin{array}{l}6 \\
7\end{array}$ & $\begin{array}{l}6 \\
7\end{array}$ & $\begin{array}{l}6 \\
9\end{array}$ & $\begin{array}{l}6 \\
9\end{array}$ & $\begin{array}{l}7 \\
0\end{array}$ & \multirow{3}{*}{ HG } \\
\hline \multirow{2}{*}{ L1 gene variability } & 6 & 7 & 7 & $\begin{array}{l}9 \\
1\end{array}$ & 9 & 0 & \\
\hline & $\begin{array}{l}8 \\
6\end{array}$ & $\begin{array}{l}0 \\
6\end{array}$ & $\begin{array}{l}4 \\
4\end{array}$ & $\begin{array}{l}1 \\
3\end{array}$ & $\begin{array}{l}4 \\
7\end{array}$ & $\begin{array}{l}0 \\
3\end{array}$ & \\
\hline $\begin{array}{l}\text { Prototype } \\
\text { (NC_001593.1) }\end{array}$ & C & $\mathrm{C}$ & A & G & $\mathrm{C}$ & G & \\
\hline $6 \mathrm{SE}$ & $\mathrm{T}$ & $\mathrm{T}$ & G & A & $\mathrm{T}$ & A & CIN III \\
\hline Protein & & & & & & $\mathrm{P} 430 \mathrm{~S}$ & \\
\hline Hydropathic index & & & & & & $\begin{array}{c}\text { Hydrophobic/ } \\
\text { Hydrophilic }\end{array}$ & \\
\hline $\begin{array}{l}\text { Biological functions } \\
\text { altered }\end{array}$ & & & & & & $\begin{array}{c}\text { MHC Class-I/ } \\
\text { B-cell }\end{array}$ & \\
\hline
\end{tabular}

(b)

\begin{tabular}{|c|c|c|c|c|c|c|c|}
\hline & 6 & 6 & 6 & 6 & 6 & 6 & \multirow{4}{*}{$\mathrm{HG}$} \\
\hline HPV-54 & 5 & 5 & 6 & 6 & 6 & 9 & \\
\hline \multirow[t]{2}{*}{ L1 gene variability } & 5 & 7 & 2 & 2 & 2 & 7 & \\
\hline & 2 & 9 & 2 & 4 & 5 & 5 & \\
\hline $\begin{array}{l}\text { Prototype } \\
\text { (NC_001676.1) }\end{array}$ & A & G & A & A & $\mathrm{T}$ & $\mathrm{C}$ & \\
\hline $233 \mathrm{PE}$ & $\mathrm{T}$ & A & $\mathrm{T}^{*}$ & $\mathrm{~T}$ & $\mathrm{C}^{*}$ & $\mathrm{~T}$ & CIN I \\
\hline Protein & Q313H & & T337S & T337S & & & \\
\hline Hydropathic index & $\begin{array}{l}\text { Hydrophilic/ } \\
\text { Hydrophilic }\end{array}$ & & Hydrophilic & Hydrophilic & & & \\
\hline $\begin{array}{l}\text { Biological functions } \\
\text { altered }\end{array}$ & $\begin{array}{l}\text { MHC Class-I/ } \\
\text { MHC Class-II/ } \\
\text { B-cell }\end{array}$ & & $\begin{array}{l}\text { MHC Class-I/ } \\
\text { MHC Class-II/ } \\
\text { B-cell }\end{array}$ & $\begin{array}{c}\text { MHC Class-I/ } \\
\text { MHC Class-II/ } \\
\text { B-cell }\end{array}$ & & & \\
\hline
\end{tabular}

TABle 4: Amino acid residue changes mapped into T-cell epitopes. The amino acids in bold and italic are the positions of change in the predicted T-cell epitopes.

\begin{tabular}{lc}
\hline $\begin{array}{l}\text { L1 epitopes prediction for T-cell } \\
\text { epitopes }\end{array}$ & $\begin{array}{c}\text { Amino acid change insered } \\
\text { in epitope sequence }\end{array}$ \\
\hline QKDQPPPEKQDPL & P430S \\
YWLQRAQGQNNGI & Q313H \\
TTRSTNLTLCATAST & T337S \\
NGICWFNELFVTVVDTT & E329D \\
FTICTASTAAAEYKATNFR & A351T, E354D \\
FDLQFIFQLCKIQLTPEIMAY & Q328R \\
HYLQSRAITCQKGA & T427A \\
IACQKDAPTPEKKDPY & T433A \\
\hline
\end{tabular}

The genetic variability in L1 protein of HPV-62 showed nine nucleotide exchanges, five of which are nonsynonymous mutations. Among these, two new mutations were found at 6838C and A6921G, which led to E354D and Q382R changes in amino acid, respectively (Table 7). With regard to the altered biological functions, some of these mutation points are included in the $\mathrm{T}$-cell and $\mathrm{B}$-cell epitope binding regions (Table 7) (Tables 4 and 5).
TABle 5: Amino acid residue changes mapped into B-cell epitopes. The amino acids in bold and italic are the positions of change in the predicted B-cell epitopes.

\begin{tabular}{lc}
\hline L1 epitopes prediction for B-cell & $\begin{array}{c}\text { Amino acid change insered } \\
\text { in epitope sequence }\end{array}$ \\
\hline TCQKDQPPPEKQDPLSKYKFWEV & P430S \\
EYQIFNKPYWLQRAQGQNNGI & Q313H \\
VDTTRSTNLT & T337S \\
NELFVTVVDTT & E329D \\
AEYKATNFREFLRHTEEFDLQ & E354D \\
LQFIFQLCKIQLTPE & Q382R \\
CQKDAPTPEKKDPYDDLKF & T433A \\
\hline
\end{tabular}

\section{Discussion}

This study described the presence of rare HPV genotypes in CIN I, III and invasive cancer in women from NorthEast Brazil. The results of this study showed thirty nucleotide changes, nine of which were reported for the first time. Moreover, this study showed the predominance of Alpha-9 and a low frequency of Alpha-7 species in cervical lesions. These correspond to epidemiological data from the rest of the world, which have shown that Alpha-9 is the main species 
TABLE 6: Nucleotide sequence variation in the L1 gene of HPV-56, HPV-70, and HPV-81. The vertical numbers indicate the position of the nucleotide variations. HG: Histopathological grade. $\left({ }^{*}\right)$ Substitutions not previously reported. (.) Similar to the prototype sequence.

(a)

\begin{tabular}{lccc}
\hline & 7 & 7 & \\
HPV-81 & 1 & 2 & HG \\
L1 gene variability & 4 & 4 & \\
\hline Prototype & 8 & 9 & \\
(AJ620209.1) & A & T & CIN I \\
106 PE & $\mathrm{G}^{*}$ & $\mathrm{~A}^{*}$ & \\
\hline
\end{tabular}

(b)

\begin{tabular}{llll}
\hline & 6 & 6 & \\
HPV-56 & 6 & 9 & HG \\
L1 gene variability & 6 & 8 & \\
& 6 & 7 & \\
\hline Prototype (X74483.1) & A & A & \multirow{2}{*}{ CIN I } \\
35 SE & G & G & \\
\hline
\end{tabular}

(c)

\begin{tabular}{lcccccc}
\hline & 6 & 6 & 6 & 6 & 6 & \\
HPV-70 & 6 & 7 & 8 & 8 & 8 & HG \\
L1 gene variability & 3 & 4 & 0 & 7 & 8 & \\
& 3 & 1 & 1 & 3 & 6 & CIN I \\
Prototype (HPU21941) & $\mathrm{G}$ & $\mathrm{T}$ & $\mathrm{A}$ & $\mathrm{A}$ & $\mathrm{A}$ & Adenocarcinoma \\
$41 \mathrm{PE}$ & $\mathrm{A}$ & $\cdot$ & $\cdot$ & $\cdot$ & $\mathrm{G}^{*}$ & \\
$42 \mathrm{PE}$ & $\mathrm{A}$ & $\mathrm{A}$ & $\mathrm{C}^{*}$ & $\mathrm{G}^{*}$ & T433A & \\
Protein & & & & & Hydrophilic/ & \\
Hydropathic index & & & & & MHC Class-I & \\
Biological functions & & & & & & \\
altered & & & & & & \\
\hline
\end{tabular}

TABLE 7: Nucleotide sequence variation in the L1 gene of HPV-62. The vertical numbers indicate the position of the nucleotide variations. HG: Histopathological grade. $\left({ }^{*}\right)$ Substitutions not previously reported.

\begin{tabular}{|c|c|c|c|c|c|c|c|c|c|c|}
\hline & 6 & 6 & 6 & 6 & 6 & 6 & 7 & 7 & 7 & \multirow{4}{*}{ HG } \\
\hline HPV-62 & 7 & 8 & 8 & 8 & 9 & 9 & 0 & 1 & 1 & \\
\hline \multirow{2}{*}{ L1 gene variability } & 6 & 2 & 3 & 4 & 2 & 2 & 5 & 1 & 5 & \\
\hline & 3 & 7 & 8 & 7 & 1 & 5 & 5 & 4 & 9 & \\
\hline $\begin{array}{l}\text { Prototype } \\
\text { (AY395706) }\end{array}$ & A & G & A & $\mathrm{T}$ & A & A & A & $\mathrm{A}$ & $\mathrm{C}$ & \\
\hline $165 \mathrm{PE}$ & $\mathrm{C}$ & A & $\mathrm{C}^{*}$ & C & $\mathrm{G}^{*}$ & G & G & $\mathrm{C}$ & $\mathrm{T}$ & CIN III \\
\hline Protein & E329D & A351T & E354D & & Q382R & & T427A & & & \\
\hline Hydropathic index & $\begin{array}{l}\text { Hydrophilic/ } \\
\text { Hydrophobic }\end{array}$ & $\begin{array}{l}\text { Hydrophobic/ } \\
\text { Hydrophilic }\end{array}$ & $\begin{array}{l}\text { Hydrophobic/ } \\
\text { Hydrophobic }\end{array}$ & & $\begin{array}{l}\text { Hydrophilic/ } \\
\text { Hydrophilic }\end{array}$ & & $\begin{array}{l}\text { Hydrophilic/ } \\
\text { Hydrophobic }\end{array}$ & & & \\
\hline $\begin{array}{l}\text { Biological } \\
\text { functions altered }\end{array}$ & $\begin{array}{l}\text { MHC Class-I/ } \\
\text { MHC Class-II/ } \\
\text { B-cell epitopes }\end{array}$ & $\begin{array}{l}\text { MHC Class-I/ } \\
\text { MHC Class-II }\end{array}$ & $\begin{array}{l}\text { MHC Class-II/ } \\
\text { B-cell epitopes }\end{array}$ & & $\begin{array}{l}\text { MHC Class-I/ } \\
\text { MHC Class-II/ } \\
\text { B-cell epitopes }\end{array}$ & & $\begin{array}{l}\text { MHC Class-I/ } \\
\text { MHC Class-II }\end{array}$ & & & \\
\hline
\end{tabular}

involved in cervical cancer [9]. Furthermore, this study found low frequencies of Alpha-6, Alpha-10, Alpha-3, and Alpha-1 species in cervical lesions or cervical cancer.

Recently, epidemiological data on the worldwide incidence of HPV have provided evidence that $2.25 \%$ of total invasive cervical cancer was caused by rare HPV types
$[9,30]$. This study showed that $9.47 \%$ of cervical samples were infected with rare HPV types, while $7.37 \%$ were infected with rare HPV but without coinfection with other Alpha9 species. Despite the low frequency of these viruses on an individual basis, when all the prevalence data were collated, it was confirmed that rare HPV types are the second most 
common groups of viruses in cervical lesions of women from North-East Brazil. In addition, recent biological studies have reported that all HPV within Alpha-5, 6, 7, 9, and 11 species contain E6 oncoprotein that degrades p53 [31, 32]. This evidence suggests that rare HPV types play a putative role in carcinogenesis.

The use of PCR with MY09/11 degenerate primers followed by direct sequencing allows other Alpha species to be detected, apart from the Alpha-9 virus group. This study reported rare HPV types, including new variants that were occasionally characterized as single infections. Rare HPV types have also been detected as a single infection in invasive cancer in other studies [9].

Some of the rare HPV types found in cervical lesions or cervical cancer in this study are not considered as carcinogenic viruses [8]. Hence, we speculate that the abovementioned genetic variations in rare HPV types might be involved in carcinogenesis due to their higher infection ability. The genetic variations reported in this study could reduce the neutralizing effect of antibodies or make more efficient the interaction between virus and cellular membrane, thus allowing a more effective infection. However, further studies should be performed to demonstrate whether these rare HPV types and their variants can be regarded as carcinogenic.

In conclusion, this study found a predominance of Alpha9 species in CIN I, III and invasive cancer in infected women from North-East Brazil. Moreover, genetic variability in L1 genes showed several synonymous and nonsynonymous mutations, which can lead to an altered immune response. Further investigation of the prevalence and variability of rare HPV types can clarify the role of this virus in infections and carcinogenesis.

\section{Conflict of Interests}

The authors declare that there is no conflict of interests.

\section{Authors' Contribution}

Ana Pavla Almeida Diniz Gurgel carried out all the experiments and wrote the paper; Maria Tereza C. Muniz and Jacinto da Costa Silva Neto were responsible for the data collection; Bárbara Simas Chagas, Carolina Maria Medeiros do Amaral and participated in some of the experiments; Eugenia M. B. Albuquerque and Ivi Gonçalves G. S. Serra are Gynecologists and were involved in the collection of the samples; Antonio Carlosde Freitas is the supervisor of this study and reviewed the final draft of this paper.

\section{Acknowledgments}

This research was supported by the Coordenação de Aperfeiçoamento de Pessoal de Nível Superior (CAPES), Conselho Nacional de Desenvolvimento Científico e Tecnológico $(\mathrm{CNPq})$, and Fundação de Amparo à Ciência e Tecnologia do Estado de Pernambuco (FACEPE).

\section{References}

[1] A. Jemal, F. Bray, M. M. Center, J. Ferlay, E. Ward, and D. Forman, "Global cancer statistics," CA Cancer Journal for Clinicians, vol. 61, no. 2, pp. 69-90, 2011.

[2] A. C. De Freitas, "Vaccine strategies against human papillomavirus: a discussion focused on developing countries," Journal of Clinical \& Cellular Immunology, vol. 1, no. S4, 2012.

[3] H. Zur Hausen, "Papillomavirus infections-a major cause of human cancers," Biochimica et Biophysica Acta, vol. 1288, no. 2, pp. F55-F78, 1996.

[4] A. C. De Freitas, A. P. A. D. Gurgel, B. S. Chagas, E. C. Coimbra, and C. M. M. Do Amaral, "Susceptibility to cervical cancer: an overview," Gynecologic Oncology, vol. 126, no. 2, pp. 304-311, 2012.

[5] H. U. Bernard, R. D. Burk, Z. Chen, K. van Doorslaer, H. Z. Hausen, and E. M. de Villiers, "Classification of papillomaviruses (PVs) based on $189 \mathrm{PV}$ types and proposal of taxonomic amendments," Virology, vol. 401, no. 1, pp. 70-79, 2010.

[6] E. M. De Villiers, C. Fauquet, T. R. Broker, H. U. Bernard, and H. Zur Hausen, "Classification of papillomaviruses," Virology, vol. 324, no. 1, pp. 17-27, 2004.

[7] H. Zur Hausen, "Papillomaviruses and cancer: from basic studies to clinical application," Nature Review Cancer, vol. 2, no. 5, pp. 342-350, 2002.

[8] M. Schiffman, G. Clifford, and F. M. Buonaguro, "Classification of weakly carcinogenic human papillomavirus types: addressing the limits of epidemiology at the borderline," Infectious Agents and Cancer, vol. 4, no. 1, article 8, 2009.

[9] S. de Sanjose, W. G. V. Quint, L. Alemany et al., "Human papillomavirus genotype attribution in invasive cervical cancer: a retrospective cross-sectional worldwide study," The Lancet Oncology, vol. 11, no. 11, pp. 1048-1056, 2010.

[10] M. F. P. T. Baldez Da Silva, B. S. Chagas, V. Guimarães et al., "HPV31 and HPV33 incidence in cervical samples from women in Recife, Brazil," Genetics and Molecular Research, vol. 8, no. 4, pp. 1437-1443, 2009.

[11] B. S. Chagas, M. V. A. Batista, V. Guimarães, V. Q. Balbino, S. Crovella, and A. C. Freitas, "New variants of E6 and E7 oncogenes of human papillomavirus type 31 identified in Northeastern Brazil," Gynecologic Oncology, vol. 123, no. 2, pp. 284-288, 2011.

[12] M. R. Pillai, R. Hariharan, J. M. Babu et al., "Molecular variants of HPV-16 associated with cervical cancer in Indian population," International Journal of Cancer, vol. 125, no. 1, pp. 91-103, 2009.

[13] T. R. Alencar, D. M. Cerqueira, M. R. D. Cruz, P. S. Wyant, E. D. Ramalho, and C. R. F. Martins, "New HPV-16 European and non-European variants in Central Brazil," Virus Genes, vol. 35, no. 1, pp. 1-4, 2007.

[14] D. M. Cerqueira, T. Raiol, N. M. C. Véras et al., "New variants of human papillomavirus type 18 identified in central Brazil," Virus Genes, vol. 37, no. 2, pp. 282-287, 2008.

[15] T. Raiol, P. S. Wyant, R. M. S. De Amorim et al., "Genetic variability and phylogeny of the high-risk HPV-31, -33, -35, 52, and -58 in Central Brazil," Journal of Medical Virology, vol. 81, no. 4, pp. 685-692, 2009.

[16] M. M. Castro, I. P. Farias, C. M. Borborema-Santos, G. Correia, and S. Astolfi-Filho, "Prevalence of human papillomavirus (HPV) type 16 variants and rare HPV types in the central Amazon region.," Genetics and Molecular Research, vol. 10, no. 1, pp. 186-196, 2011. 
[17] S. Pande, N. Jain, B. K. Prusty et al., "Human papillomavirus type 16 variant analysis of E6, E7, and L1 genes and long control region in biopsy samples from cervical cancer patients in North India," Journal of Clinical Microbiology, vol. 46, no. 3, pp. 10601066, 2008.

[18] I. E. Calleja-Macias, L. L. Villa, J. C. Prado et al., "Worldwide genomic diversity of the high-risk human papillomavirus types $31,35,52$, and 58 , four close relatives of human papillomavirus type 16," Journal of Virology, vol. 79, no. 21, pp. 13630-13640, 2005.

[19] I. E. Calleja-Macias, M. Kalantari, J. Huh et al., "Genomic diversity of human papillomavirus-16, 18, 31, and 35 isolates in a Mexican population and relationship to European, African, and Native American variants," Virology, vol. 319, no. 2, pp. 315-323, 2004.

[20] G. Cornut, S. Gagnon, C. Hankins et al., "Polymorphism of the capsid L1 gene of human papillomavirus types 31, 33, and 35," Journal of Medical Virology, vol. 82, no. 7, pp. 1168-1178, 2010.

[21] H. Arias-Pulido, C. L. Peyton, N. Torrez-Martínez, D. N. Anderson, and C. M. Wheeler, "Human papillomavirus type 18 variant lineages in United States populations characterized by sequence analysis of LCR-E6, E2, and Llregions," Virology, vol. 338, no. 1, pp. 22-34, 2005.

[22] J. C. Prado, I. E. Calleja-Macias, H. U. Bernard et al., "Worldwide genomic diversity of the human papillomaviruses-53, 56, and 66, a group of high-risk HPVs unrelated to HPV-16 and HPV-18," Virology, vol. 340, no. 1, pp. 95-104, 2005.

[23] V. Cento, N. Rahmatalla, M. Ciccozzi, A. Lo Presti, C. F. Perno, and M. Ciotti, "Human Papillomaviruses 53 and 66: clinical aspects and genetic analysis," Virus Research, vol. 163, no. 1, pp. 212-222, 2012.

[24] F. Karlsen, M. Kalantari, A. Jenkins et al., "Use of multiple PCR primer sets for optimal detection of human papillomavirus," Journal of Clinical Microbiology, vol. 34, no. 9, pp. 2095-2100, 1996.

[25] R. Staden, "The staden sequence analysis package," Applied Biochemistry and Biotechnology B, vol. 5, no. 3, pp. 233-241, 1996.

[26] K. Tamura, D. Peterson, N. Peterson, G. Stecher, M. Nei, and S. Kumar, "MEGA5: molecular evolutionary genetics analysis using maximum likelihood, evolutionary distance, and maximum parsimony methods," Molecular Biologica Land Evolution, vol. 28, no. 10, pp. 2731-2739, 2011.

[27] S. Saha and G. P. S. Raghava, "BcePred: prediction of continuous B-cell epitopes in antigenic sequences using physico-chemical properties," in Proceedings of the 3rd International Conference on Artificial Immune Systems (ICARIS '04), G. Nicosia, V. Cutello, P. J. Bentley, and J. Timis, Eds., vol. 3239 of LNCS, pp. 197-204, Springer, 2004.

[28] H. Singh and G. P. S. Raghava, "ProPred1: prediction of promiscuous MHC Class-I binding sites," Bioinformatics, vol. 19, no. 8, pp. 1009-1014, 2003.

[29] H. Singh and G. P. Raghava, "ProPred: prediction of HLA-DR binding sites," Bioinformatics, vol. 17, no. 12, pp. 1236-1237, 2001.

[30] D. Geraets, L. Alemany, N. Guimera et al., "Detection of rare and possibly carcinogenic Human Papillomavirus genotypes as single infections in invasive cervical cancer," The Journal of Pathology, vol. 228, no. 4, pp. 534-543, 2012.

[31] L. Fu, K. van Doorslaer, Z. Chen et al., "Degradation of p53 by human Alphapapillomavirus E6 proteins shows a stronger correlation with phylogeny than oncogenicity," PLOS ONE, vol. 5, no. 9, Article ID e12816, pp. 1-8, 2010.
[32] T. Mesplède, D. Gagnon, F. Bergeron-Labrecque et al., "p53 degradation activity, expression, and subcellular localization of E6 proteins from 29 human papillomavirus genotypes," Journal of Virology, vol. 86, no. 1, pp. 94-107, 2012. 


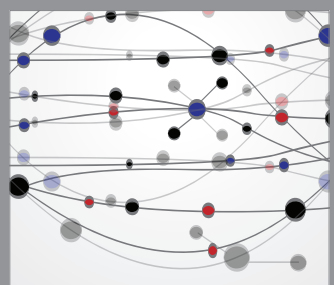

The Scientific World Journal
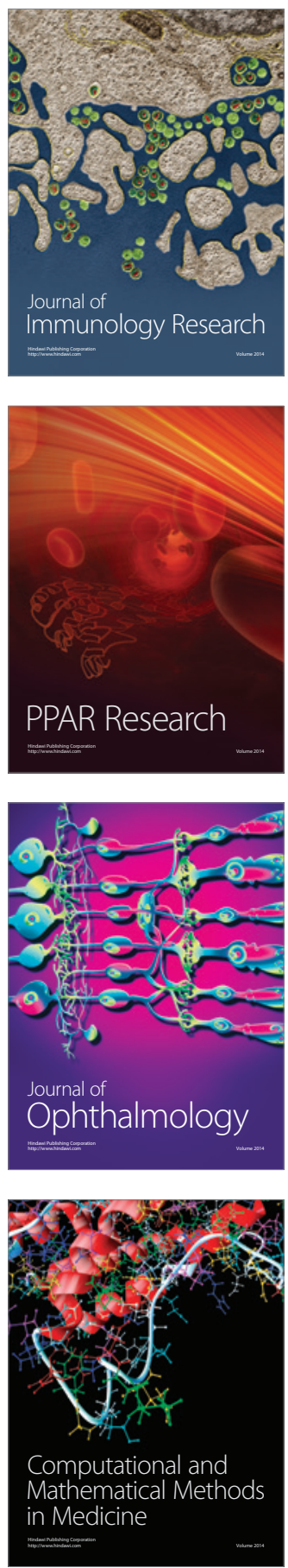

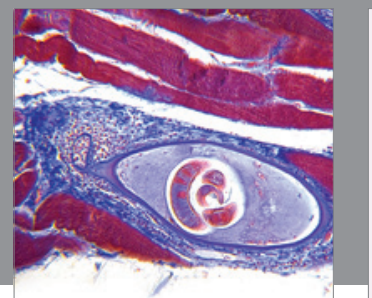

Gastroenterology

Research and Practice
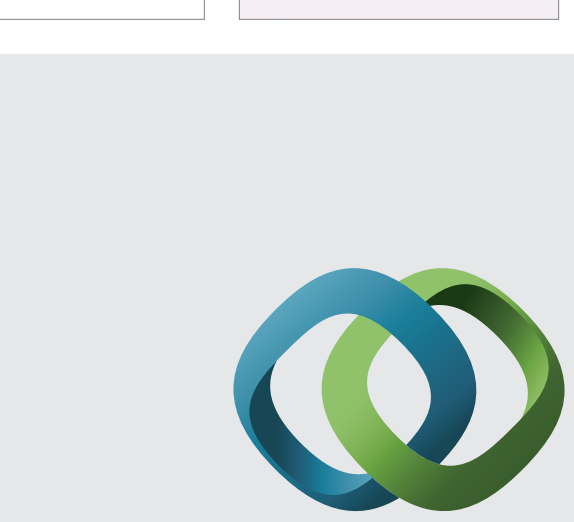

\section{Hindawi}

Submit your manuscripts at

http://www.hindawi.com
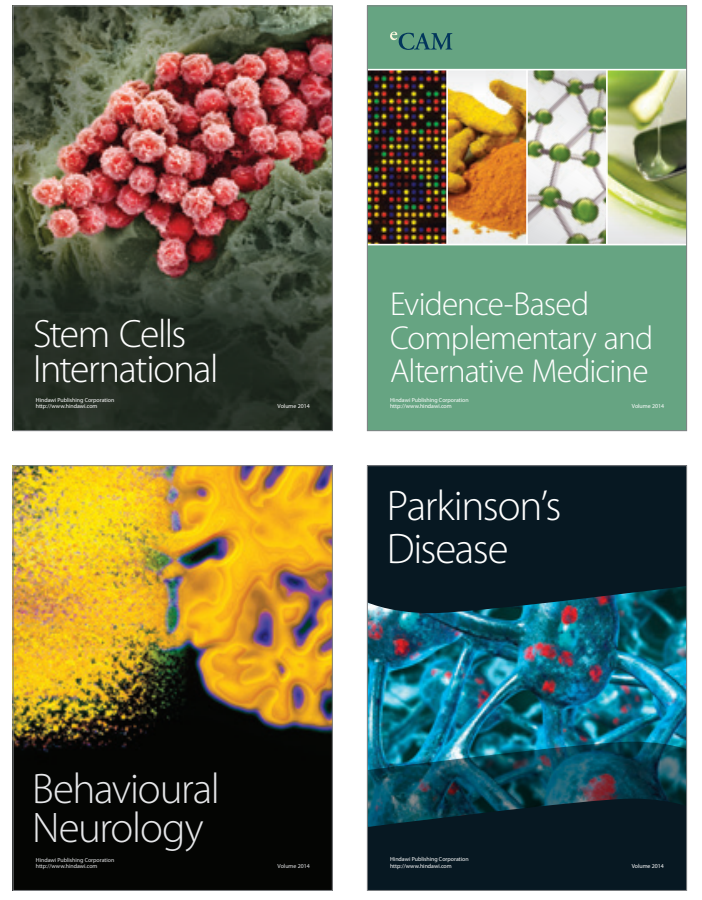
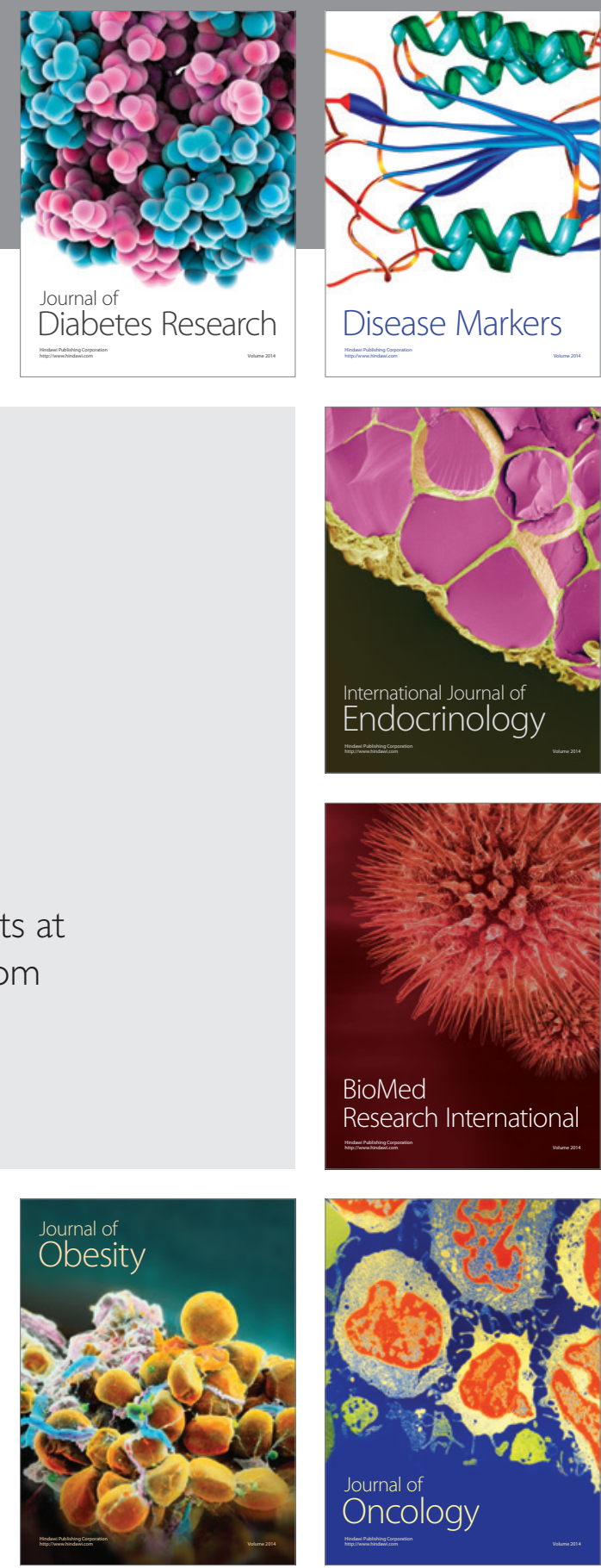

Disease Markers
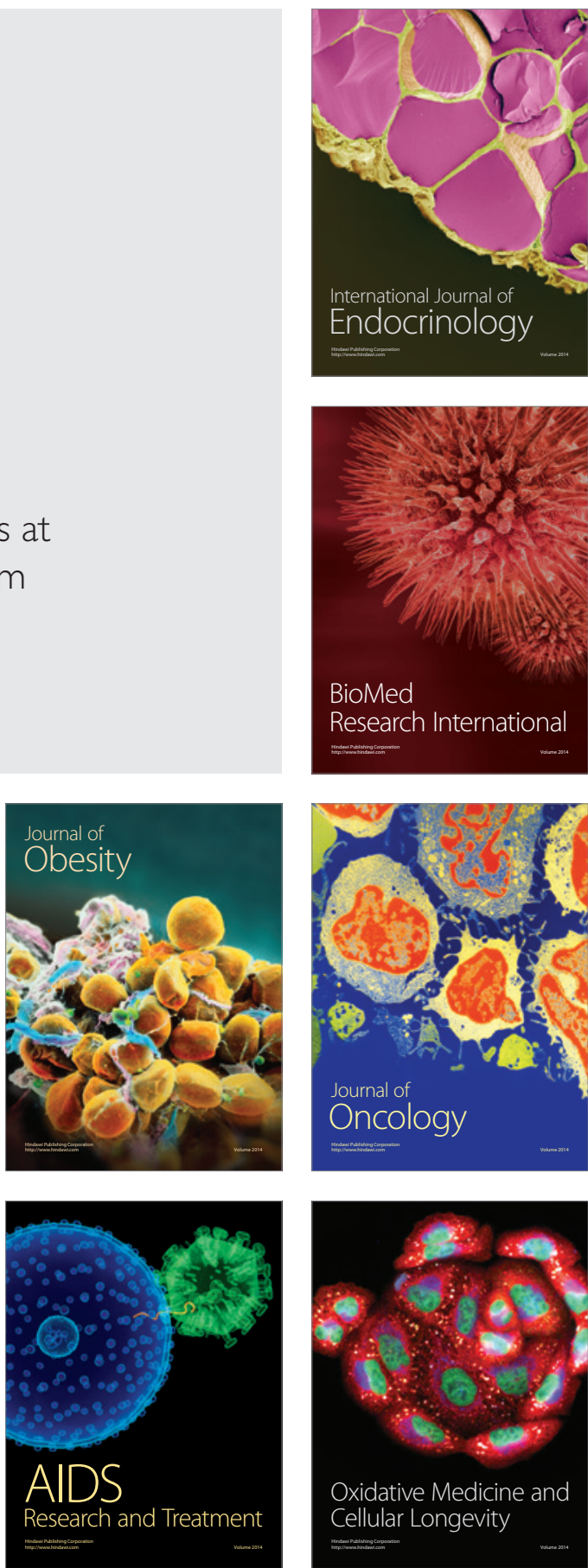